\title{
EFFICACY OF STRAINS OF METARHIZIUM ANISOPLIAE(METSCH) SOROKIN WITH THEIR DIFFERENT PREPARATIONS AGAINST WHITE GRUB (CHILOLOBA ACUTA) IN VITRO IN NEPAL
}

\begin{abstract}
Dipak Khanal ${ }^{1}$, Yubak D. GC ${ }^{2}$, Yagya P. Giri ${ }^{3}$, Marc Sporleder $^{4}$ and Resham B. Thapa ${ }^{1}$ ABSTRACT

Laboratory studies were conducted to evaluate the virulence of an indigenous and a commercial strain of the entomopathogenic fungi, Metarhiziuma nisopliae(Metsch.) Sorokin in three different preparations against third instars larva of Chiloloba acuta.Conidia of the indigenous strain were multiplied on barley grain, ("Ind-G") while the commercial strain was tested in its powder ("Com-P") and solution ("Com-S") preparations. All fungus preparations were bioassayed at different concentrations levels; i.e. "Ind-G" at $60,10,1.66,0.27,0.046 \mathrm{~g} / \mathrm{kg}$ of soil, "Com-P" at 10, 1.66, 0.27, 0.046, 0.0077g/ kg of soil and "Com-S" at 10, 1.66, 0.27, 0.046, 0.0077g /(100 ml water+ $1 \mathrm{~kg}$ soil). The $L C_{50}$-value of Ind-G $(0.41 \mathrm{~g} / \mathrm{kg}$ of soil) was higher as compared to Com- $P(0.11 \mathrm{~g} / \mathrm{kg}$ of soil) and Com-S $(0.10 \mathrm{~g} / \mathrm{kg}$ of soil) revealing relative potencies of $1,3.27$ (CL 95\% ranging 1.01-10.29) and 4.11(CL 95\% ranging 1.28 to13.01), respectively at 40 days after inoculation (DAI). Based on this study there is great possibility that the entomopathogenic fungi could be a safe microbial control agents in managing white grubs.
\end{abstract}

Key words: Bioassay, efficacy, Entomopathogenic fungi, $\mathrm{LC}_{50}$, white grubs,

\section{INTRODUCTION}

Insect pests are major limiting factors to crop production system, which cause about 12-15\% crop losses worldwide (Upadhyaya, 2003) and 15- 20\% in Nepal (Joshi et al., 1991; Palikheet al., 2003). Among them, soil insect pests are becoming major biological constrains to the productivity of different crops (Oya, 1996; Guppy and Harcourt, 1970; Potter et al., 1992). The extent of damage caused by white grubs (Coleoptera: Scarabaeidae) solely depends upon the species involved, the number present and the host crops. The damaged caused by scarabaeidae larvae is estimated to reduce the crop yield by about $40-80 \%$ (Prasad and Thakur, 1959; Raodeo, 1974), and in a more recent study by about 12-60\% (Pokhrel, 2004). However insecticides have been found ineffective in controlling scarabaeidae larvae (NMRP, 1997) because the larvae present in the soil do not come into direct contact with the insecticides, which is generally applied during the growing season (Oya, 1995) and have even shown resistance to organochlorine (Pokhrel, 2004). Scheduled chemical application is ineffective (Schweigkofler and Zelger, 2002) and in Nepalese context farmers are not considering economic threshold of pests, but applying pesticides at higher dosages than it is required (Maharjan et al., 2004). Due to the various negative effects of chemical pesticides on non-target organisms have forced the industry and scientists to focus on the development of alternative control measures. Theentomopathogenic fungus (EPF)

\footnotetext{
${ }^{1}$ Institute of Agriculture and Animal Science (IAAS), Rampur, Chitwan, Nepal

${ }^{2}$ Department of Agriculture, HariharBhawan, Kathmandu, Nepal

${ }^{3}$ Nepal Agriculture Research Council, (NARC)

${ }^{4}$ International Potato Center (CIP)
} 
Metarhiziumanisopliaeis one of the most reviewed, studied and applied species amongst fungal bio-control agents, and several commercial products have been developed and registered for the control of different insect pests (Butt et al., 2001; Ferron, 1985; Upadhyay, 2003). M. anisopliae, as being environmentally friendly and also likely to be self-perpetuating (Mazodze and Zvoutete, 1999) and has no mammalian toxicity. Also microbial control has evolved worldwide as an important component of IPM, with success in Asia and South America (Fuxa, 1987) although it is still in rudimentary stages in Nepal. Hence in this study $M$. anisopliae had used as a biological control agent to minimize the use and ill effects of the pesticide for possible integration in the IPM program.

\section{OBJECTIVE}

The objective of this study was to compare the biological activity between an indigenous and a commercial strain (Pacer, wettable powder) of M. anisopliaein three different preparations against white grubs in the laboratory.

\section{MATERIALS AND METHODS}

\section{FUNGUS STRAINS}

Two strains of M. anisopliae, indigenous and commercial, were used in this experiment. The indigenous strain was collected from the Insect Pathology Unit, Entomology Department, Institute of Agriculture and Animal Science (IAAS). The commercial product was "Pacer" (Agri Life Medak, India) available in wettable powder (WP) formulation contains $1.15 \%$ of M. anisopliae corresponding to $10^{8}$ conidia forming units (CFU) per gram dry weight of the product.

Blastospores of indigenous strain were prepared using liquid medium which contains two suspensions, one with $500 \mathrm{ml}$ tap water, $20 \mathrm{~g}$ Corn steep, $2.26 \mathrm{~g}$ $\mathrm{KH}_{2} \mathrm{PO}_{4}$ and $3.8 \mathrm{Na}_{2} \mathrm{HPO}_{4}$ (suspensions "A") and other with $500 \mathrm{ml}$ tap water with $30 \mathrm{~g}$ glucose (suspensions "B"). These suspensions were autoclaved separately at 1.5 bar $\left(121^{\circ} \mathrm{C}\right)$ for $40 \mathrm{~min}$ and later mixed together. Blastospores were prepared in such medium into flasks after shaking them at $100-120 \mathrm{rpm}$ for 5-6 days. The process was conducted at $220^{\circ} \mathrm{C}$ in UV protected room. Each flask containing the blastospores suspension was diluted at 1:1 ratio with the addition of $100 \mathrm{ml}$ of sterilized tap water. Peeled grains of barley were used as growing solid substrates. The bags containing barley grains were shaked daily in order to achieve homogenous growth of the fungus through improved aeration and preventing the kernels from sticking together. After two weeks the barley kernels were found to be fully colonized by fungal conidia (Ind-G), which were then ready to use in the experiments.

\section{INSECT COLLECTION}

For bioassay, white grublarvae of Chiloloba acuta were collected from Kulekhani

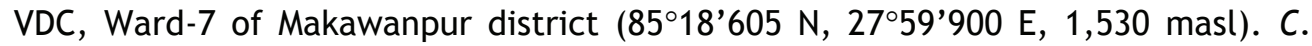
acutawas collected beneath the crop root level and placed individually in $100 \mathrm{ml}$ vials $(\varnothing=5.5 \mathrm{~cm}, 6 \mathrm{~cm}$ height). The vials were closed with perforated lids and brought to the laboratory (Entomology Division NARC, Lalitpur). In the laboratory, 
white grubs were transferred into rearing vials $(5 \mathrm{~cm} \cdot 5.5 \mathrm{~cm}, \mathrm{~d} \cdot \mathrm{h})$ filled with soil carried from the field of grub collection and a slice of potato and decomposed organic matter as food for the larva. Rearing vials were kept at ambient room temperature $\left(25 \pm 5^{\circ} \mathrm{C} ; 75 \pm 5 \% \mathrm{RH}\right)$ for a 10 -day quarantine period; larvae that showed symptoms of any disease were discarded. Only non-infected and morphologically identical larvae were used in the bioassays.

\section{SOILS}

Soil samples were analyzed at the Soil Science Division, NARC, Khumaltar for the physio-chemical properties. The analysis revealed a $\mathrm{pH} 6.3$, and a composition of $53.3 \%$ sand, $34.5 \%$ silt, and $12.2 \%$ clay (class: silty loam).

\section{PREPARATION OF CONCENTRATION LEVELS OF INDIGENOUS STRAIN MULTIPLIED IN BARLEY GRAIN (IND-G)}

For the highest concentration level $150 \mathrm{~g}$ of M.anisopliae developed on barley grain was mixed with $2.5 \mathrm{~kg}$ of sterilized soil (@60g/ $\mathrm{kg}$ of soil) for few minutes. Further concentration levels were obtained through sequential dilution using a dilution factor 6 ; i.e. $40 \mathrm{~g}$ of soil were removed from the stock mixture and mixed with $2 \mathrm{~kg}$ sterilized soil to obtain the second dose. This step was repeated until five fungus-soil preparations with the concentration of $60,10,1.66,0.27,0.046 \mathrm{~g}$ of the fungus product per kg of soil was obtained (Table 1).

\section{PREPARATIONOF CONCENTRATION LEVELS OF COMMERCIAL STRAIN APPLIED IN POWDER PREPARATION (COM - P)}

Twenty five gram Pacer powder (M. anisopliae, Commercial strain) was mixed with $2.5 \mathrm{~kg}$ of sterilized soil and thoroughly agitated. The soil-fungus preparation was regarded as the stock mixture (i.e. $10 \mathrm{~g}$ powder/kg soil). From the stock mixture $40 \mathrm{~g}$ were removed and mixed with $2 \mathrm{~kg}$ sterilized soil (ratio 1:5) to obtain the next lower fungus concentration mixture (i.e. $1.66 \mathrm{~g}$ powder/kg soil) and so on upto 3 more doses with the same dilution ratio (Table 1).

\section{PREPARATION OF CONCENTRATION LEVELS OF COMMERCIAL STRAIN APPLIED IN SOLUTION PREPARATION (COM-S)}

Parcer powder $25 \mathrm{~g}$ was dissolved in $250 \mathrm{ml}$ of distilled water, which was considered as stock solution. Further dilution was done with the dilution factor 6 in a repeated dilution line $(4 \mathrm{x}) .200 \mathrm{ml}$ of respective concentrations were mixed in $2 \mathrm{~kg}$ sterilized soil and left for a day to remove excess moisture from soil (Table 1).

\section{BIOASSAY PROCEDURE}

Bioassay experiments were conducted from 1 July to 15 August, 2010 at Entomology Division, Nepal Agriculture Research Council (NARC). Soil collected from insect field was sieved and sterilized (autoclaved at $15 \mathrm{lb}$ pressure per inch and $121^{\circ} \mathrm{C}$ for $1 \mathrm{hr}$ ) then kept sealed at room temperature for a day. The experiments were completely randomized. Each treatment (Fungus preparation . concentration level) was tested with $n=35$ larvae of $C$. acuta; i.e. a total number of $N=$ (3 preparations $\cdot 5$ levels $\cdot 35$ insects $)+(35$ control $)=560$ were used in the bioassay. For each concentration, 35 larvae were placed individually in $80 \mathrm{ml}$ (5.5 
- $4.5 \mathrm{~cm}, \mathrm{~h}$. d) lid perforated plastic vial containing $40 \mathrm{~g}$ of the required fungustreated soil. The control containers were filled with untreated sterilized soil. Larvae that had not entered the soil within 15 minutes were replaced. A potato slice was placed in each container as a food source every week. The containers were incubated at room temperature.

Table 1.Preparation of concentration levels

\begin{tabular}{lllllll}
\hline Experimentt & Strain used & \multicolumn{5}{l}{ Concentration levels } \\
\cline { 3 - 7 } & & $1^{\text {st }}$ & $2^{\text {nd }}$ & $3^{\text {rd }}$ & $4^{\text {th }}$ & $5^{\text {th }}$ \\
\hline 1 & Ind-G & $60 \mathrm{~g} / \mathrm{kg}^{*}$ & $10 \mathrm{~g} / \mathrm{kg}$ & $1.66 \mathrm{~g} / \mathrm{kg}$ & $0.27 \mathrm{~g} / \mathrm{kg}$ & $0.046 \mathrm{~g} / \mathrm{kg}$ \\
2 & Com-P & $10 \mathrm{~g} / \mathrm{kg}^{* * *}$ & $1.66 / \mathrm{kg}$ & $0.27 \mathrm{~g} / \mathrm{kg}$ & $0.046 \mathrm{~g} / \mathrm{kg}$ & $0.0077 \mathrm{~g} / \mathrm{kg}$ \\
3 & Com-S & $10 \mathrm{~g} / 100 \mathrm{~m}$ & $1.66 \mathrm{~g} / 100$ & $0.27 \mathrm{~g} / 100 \mathrm{~m}$ & $0.046 \mathrm{~g} / 100 \mathrm{~m}$ & $0.0077 \mathrm{~g} / 100$ \\
& & l water & $\mathrm{ml}$ water & l water & l water & $\mathrm{ml}$ water \\
\hline
\end{tabular}

Each bioassay included one control (only sterilized soil) treatment. ${ }^{*}=\mathrm{g}$ barley grain (Indigenous strain of $M$. anisopliae multiplied)/ $\mathrm{kg}$ of soil and ${ }^{* *}=\mathrm{g}$ powder (commercial strain)/ kg of soil. ${ }^{* * *}=\mathrm{g}$ powder (commercial strain)/ (100 ml water $+1 \mathrm{~kg}$ of soil).

Mortality was assessed through direct observation of larvae in one-day interval with the first evaluation on $10^{\text {th }}$ days after inoculation (DAl) and last evaluation $40^{\text {th }}$ DAl (Table 2). During evaluation, dead larvae without visible fungal symptoms were removed from the plastic vial, placed individually in a $9 \mathrm{~cm}$ diameter Petri dish and incubated at $25^{\circ} \mathrm{C}$ and $85 \% \mathrm{RH}$ for a 7-10 day period. Growth of mycelia on the cadaver confirmed fungal disease as the cause of death and the individual was scored as dead due to fungus. Daily room temperature was recorded the full period of the bioassay. Temperature fluctuated between $29.8^{\circ} \mathrm{C}$ and $24^{\circ} \mathrm{C}$.

\section{STATISTICAL ANALYSIS}

M. anisopliae preparations were compared by their time-dose mortality curves. First, survival data from each evaluation date were submitted to probit analysis (Finney, 1971) to determine the dose-mortality relationship for each DAI. LC ${ }_{50}{ }^{-}$ values and the slope of regression line with their corresponding standard errors and confidence bands were determined for each DAl. Data from the same evaluation date were analyzed in a parallel assay. Parallelism was evaluated using a Likelihood $\mathrm{Chi}^{2}$-test ( $\mathrm{G}$-test). If the regression lines were acceptably parallel ( $\mathrm{p}$ $>0.05$ ) a common slope was used for all three Probit lines. Observed mortalities were adjusted for control mortality (dead test insects without signs of fungal disease) using Abbott's formula (Abbott 1925). Estimation of the natural mortality rate was included into the Probit model (Finney, 1971): The goodness-of-fit for regression lines were tested using a Likelihood Chi with $\mathrm{df}=$ "number of concentration levels included" - "number of parameters estimated by the model".

The second, non-linear regression was used to determine the relationship between the Probit regression parameters obtained for each evaluation day and the time after treatment. Established functions were used to express an overall dose-timemortality model that predict $\mathrm{LT}_{50}$-values for a given EPF dose. Experiments were conducted in completely randomized design. 
Table 2. Detail of the probit statistics resulting from bioassay experiments

\begin{tabular}{|c|c|c|c|c|c|c|c|c|c|c|c|}
\hline \multirow[t]{2}{*}{ DAI } & \multirow[t]{2}{*}{ Form } & \multicolumn{2}{|c|}{ Heterogeneity } & \multicolumn{2}{|c|}{ Parallelism } & \multirow{2}{*}{$\begin{array}{l}\text { LC50 } \\
\text { Spores/ml }\end{array}$} & \multicolumn{2}{|l|}{ CL95\% } & \multicolumn{3}{|l|}{ Potency } \\
\hline & & chi2 & $P$ & chi2 & $\mathrm{p}$ & & Low & High & & Low & High \\
\hline \multirow[t]{3}{*}{10} & Ind-G & 2.76 & 0.973 & 0.13 & 0.937 & 1211.56 & 25.83 & 1345715.46 & 1 & & \\
\hline & Com-s & & & & & 40.13 & 2.85 & 6224.36 & 30.19 & 2.97 & 556.15 \\
\hline & Com-P & & & & & 585.12 & 4.04 & 3301516.85 & 2.07 & 0.11 & 27.91 \\
\hline \multirow[t]{3}{*}{12} & Ind-G & 1.86 & 0.993 & 0.75 & 0.688 & 302.92 & 13.05 & 47242.25 & 1 & & \\
\hline & Com-s & & & & & 10.05 & 1.06 & 353.00 & 30.13 & 3.12 & 483.43 \\
\hline & Com-P & & & & & 124.55 & 2.77 & 52210.03 & 2.43 & 0.16 & 28.29 \\
\hline \multirow[t]{3}{*}{14} & Ind-G & 0.92 & 1.000 & 0.23 & 0.892 & 34.30 & 5.36 & 438.18 & 1.00 & & \\
\hline & Com-s & & & & & 2.61 & 0.53 & 21.51 & 13.15 & 1.83 & 111.17 \\
\hline & Com-P & & & & & 11.57 & 1.35 & 232.95 & 2.96 & 0.34 & 22.44 \\
\hline \multirow[t]{3}{*}{16} & Ind-G & 1.03 & 0.999 & 0.27 & 0.875 & 11.79 & 2.68 & 75.38 & 1.00 & & \\
\hline & Com-s & & & & & 1.43 & 0.35 & 8.04 & 8.23 & 1.24 & 57.68 \\
\hline & Com-P & & & & & 4.16 & 0.76 & 38.12 & 2.83 & 0.38 & 18.69 \\
\hline \multirow[t]{3}{*}{18} & Ind-G & 0.89 & 1.000 & 0.23 & 0.893 & 6.07 & 1.63 & 28.02 & 1.00 & & \\
\hline & Com-s & & & & & 0.75 & 0.21 & 3.16 & 8.14 & 1.34 & 51.88 \\
\hline & Com-P & & & & & 2.06 & 0.48 & 12.27 & 2.95 & 0.44 & 17.79 \\
\hline \multirow[t]{3}{*}{20} & Ind-G & 0.77 & 1.000 & 0.22 & 0.896 & 4.63 & 1.50 & 16.18 & 1.00 & & \\
\hline & Com-s & & & & & 0.58 & 0.19 & 1.94 & 7.92 & 1.62 & 40.07 \\
\hline & Com-P & & & & & 1.47 & 0.44 & 6.04 & 3.16 & 0.60 & 15.52 \\
\hline \multirow[t]{3}{*}{22} & Ind-G & 1.22 & 0.999 & 0.26 & 0.878 & 2.42 & 0.83 & 7.28 & 1.00 & & \\
\hline & Com-s & & & & & 0.44 & 0.15 & 1.33 & 5.53 & 1.19 & 25.56 \\
\hline & Com-P & & & & & 0.75 & 0.25 & 2.47 & 3.23 & 0.67 & 14.70 \\
\hline \multirow[t]{3}{*}{24} & Ind-G & 1.58 & 0.997 & 0.16 & 0.923 & 1.85 & 0.67 & 5.07 & 1.00 & & \\
\hline & Com-s & & & & & 0.36 & 0.13 & 1.00 & 5.12 & 1.22 & 21.22 \\
\hline & Com-P & & & & & 0.47 & 0.17 & 1.33 & 3.94 & 0.92 & 16.25 \\
\hline \multirow[t]{3}{*}{26} & Ind-G & 0.93 & 1.000 & 0.13 & 0.939 & 1.74 & 0.65 & 4.63 & 1.00 & & \\
\hline & Com-s & & & & & 0.27 & 0.10 & 0.71 & 6.47 & 1.61 & 26.07 \\
\hline & Com-P & & & & & 0.35 & 0.13 & 0.93 & 5.05 & 1.24 & 20.19 \\
\hline \multirow[t]{3}{*}{28} & Ind-G & 0.59 & 1.000 & 0.07 & 0.965 & 1.17 & 0.43 & 3.04 & 1.00 & & \\
\hline & Com-s & & & & & 0.23 & 0.09 & 0.60 & 5.08 & 1.29 & 19.77 \\
\hline & Com-P & & & & & 0.29 & 0.11 & 0.77 & 4.01 & 1.01 & 15.51 \\
\hline \multirow[t]{3}{*}{30} & Ind-G & 0.74 & 1.000 & 0.04 & 0.980 & 0.81 & 0.30 & 2.03 & 1.00 & & \\
\hline & Com-s & & & & & 0.20 & 0.08 & 0.50 & 4.07 & 1.08 & 14.85 \\
\hline & Com-P & & & & & 0.23 & 0.09 & 0.58 & 3.49 & 0.92 & 12.70 \\
\hline 32 & Ind-G & 0.95 & 1.000 & 0.06 & 0.969 & 0.63 & 0.22 & 1.63 & 1.00 & & \\
\hline & Com-s & & & & & 0.16 & 0.06 & 0.40 & 4.01 & 1.05 & 14.89 \\
\hline & Com-P & & & & & 0.17 & 0.06 & 0.43 & 3.73 & 0.97 & 13.81 \\
\hline 34 & Ind-G & 0.82 & 1.000 & 0.02 & 0.988 & 0.71 & 0.25 & 1.81 & 1.00 & & \\
\hline & Com-s & & & & & 0.12 & 0.04 & 0.30 & 5.97 & 1.61 & 22.21 \\
\hline & Com-P & & & & & 0.19 & 0.07 & 0.48 & 3.73 & 0.98 & 13.68 \\
\hline 36 & Ind-G & 1.47 & 0.997 & 0.02 & 0.991 & 0.59 & 0.22 & 1.45 & 1.00 & & \\
\hline & Com-s & & & & & 0.11 & 0.04 & 0.26 & 5.55 & 1.58 & 19.35 \\
\hline & Com-P & & & & & 0.14 & 0.06 & 0.35 & 4.08 & 1.15 & 14.10 \\
\hline 38 & Ind-G & 2.66 & 0.976 & 0.12 & 0.941 & 0.50 & 0.19 & 1.18 & 1.00 & & \\
\hline & Com-s & & & & & 0.10 & 0.04 & 0.23 & 5.19 & 1.58 & 16.90 \\
\hline & Com-P & & & & & 0.13 & 0.05 & 0.30 & 3.80 & 1.15 & 12.28 \\
\hline 40 & Ind-G & 2.85 & 0.970 & 0.15 & 0.926 & 0.41 & 0.15 & 0.96 & 1.00 & & \\
\hline & Com-s & & & & & 0.10 & 0.04 & 0.23 & 4.11 & 1.28 & 13.01 \\
\hline & Com-P & & & & & 0.12 & 0.05 & 0.28 & 3.27 & 1.01 & 10.29 \\
\hline
\end{tabular}

DAl= Days After Inoculation, p= Probability, CL95\%=Confidence Limit 95\% 


\section{RESULTS}

BIOLOGICAL ACTIVITY OF M. ANISOPLIAEAGAINSTC. ACUTA

The Probit model adequately described the relationship between the fungus doses and the mortality response in C. acuta for all evaluation dates (Figure 1). Chi ${ }^{2}$ values revealed a good fit of the model adjusted to the 3 fungus preparations (Table 3).
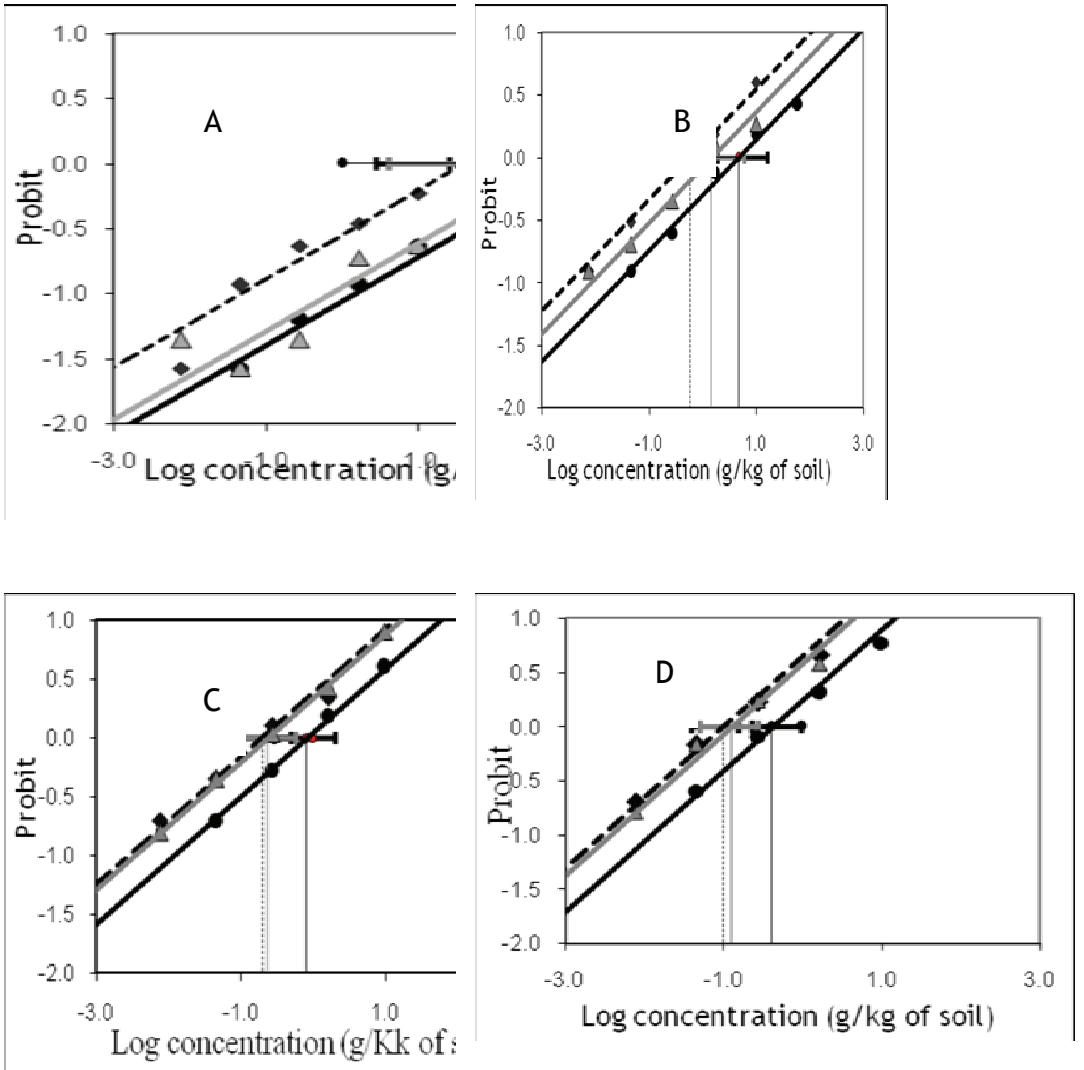

Figure 1.Probit regression line obtained for $M$. anisopliae against third instar larva ofChiloloba acuta after $10 \mathrm{DAl}$ to $40 \mathrm{DAl}$ (A, B, C, and D represent probit mortality at 10, 20, 30, and 40 DAl respectively. Black, gray, and black scatter line indicate the probit regression line of Ind-G, Com-P and Com-S, respectively while Black, gray, and black vertical line represent their respective $L_{50}$ values)

The intercept was variable at the beginning of the experiment showing increasing trend from 10 to $40 \mathrm{DAl}$ for all formulation of M. anisopliae. The intercept of Com$P$ was more or less equaled to the Ind- $G$ at the beginning of the experiment but finally it was quite near to Com-S. 
The following nonlinear model was successfully fitted to describe the relationship between time after inoculation and the intercept for both stains.

$$
\text { intercept }=a+b x+a \bar{x}
$$

Where $\mathrm{x}$ is the number of DAl and $a, b$, and $c$ are fitted parameter. The model explained $98.8 \%, 99.4 \%, 99.9 \%$ of the variation in intercepts over time for grain, liquid and powder formulation, respectively (Figure 2) model parameters and statistical details (Table 3 ).

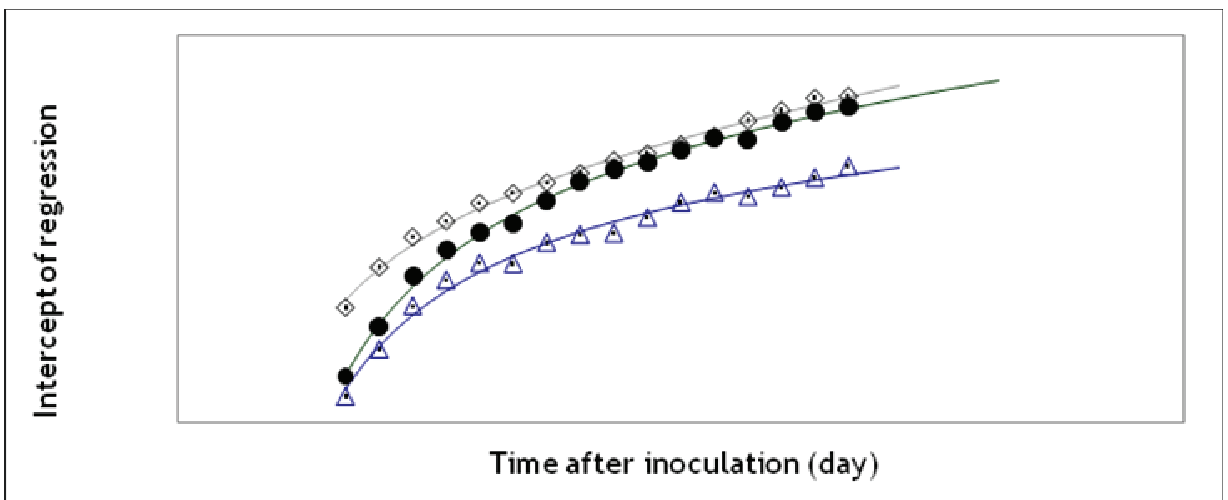

Figure 2. The intercept of probit regression line obtained during testing of the three preparaions of $M$. anisopliae against C. acuta.

Table 3. Resulting parameters in regression statistics for describing the relationship between intercept resulting from the probit analysis and DAl for different formulation of M. anisopliae against C. acuta

\begin{tabular}{llllllll}
\hline Strain & \multicolumn{2}{l}{ Parameters } & $\mathrm{R}^{2}$ & $\mathrm{~F}$ & $\mathrm{Df}$ & $\mathrm{P}$ \\
\cline { 2 - 6 } & $\mathrm{a}$ & $\mathrm{B}$ & $\mathrm{C}$ & & & & \\
\hline Ind-G & 0.345 & 0.0054 & -14.11 & 0.988 & 560 & 13 & $<0.001$ \\
& $(0.137)$ & $(0.0037)$ & $(0.1 .32)$ & & & & \\
Com-S & -8.832 & 0.0164 & 0.213 & 0.994 & 1118.0 & 13 & $<0.001$ \\
& $(0.898)$ & $(0.002)$ & $(0.093)$ & & & & \\
Com-P & -16.188 & 0.0096 & 0.597 & 0.996 & 1640 & 13 & $<0.001$ \\
& $(0.954)$ & $(0.0022)$ & $(0.098)$ & & & & \\
\hline
\end{tabular}

$\mathrm{a}, \mathrm{b}$ and $\mathrm{c}$ are model parameters; number in parentnesis indicate standard error; $\mathrm{p}=$ probability; $\mathrm{F}=$ Fisher test; $\mathrm{R}^{2}=$ Coeffecient of determination

The slopes of the regression lines for three preparations were not significantly different throughout the evaluation period for individual DAls (Table 2). The slope increased from 0.3401 at 10 DAl to 0.652 at 40 DAl almost linearly. Linear regression explained $97 \%$ of the variability of the common slope by DAI (Figure 3). The slope increased by a value of 0.011 (SE 0.00052) per day $(F=455, d f=14$, $\mathrm{p}<0.001$ ). 


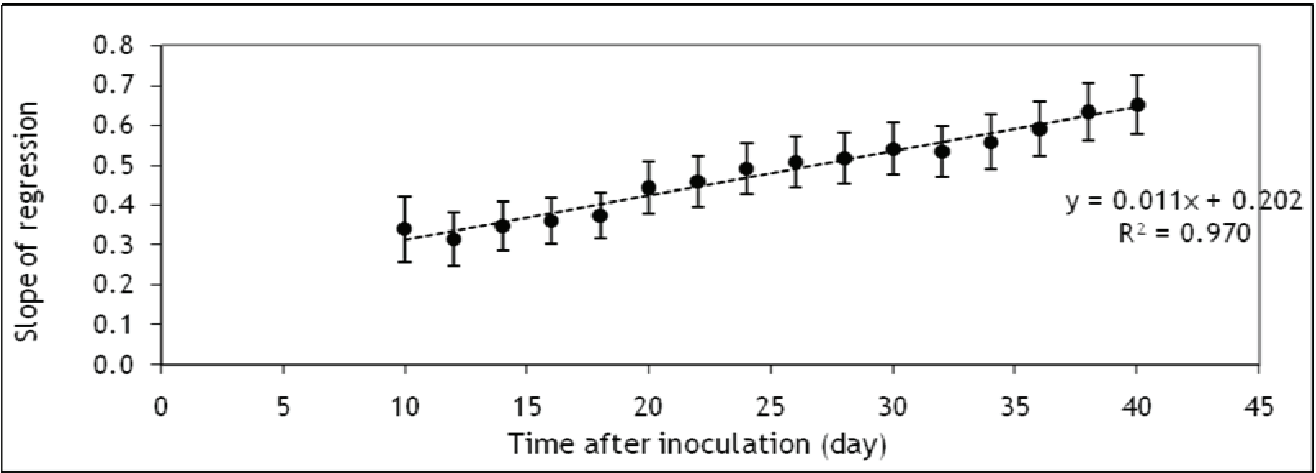

Figure 3.Regression line obtained from common slope of probitregression line during the comparison of three preparations of $M$. anisopliae against third instars larva of $C$. acuta. Black points indicate the common slope and dotted line shows the regression line of the common slope.

Obtained $\mathrm{LC}_{50}$-values for each evaluation date were plotted against the DAI, which can be taken as an estimate of the $L T_{50}$-value (in days) for the respective $M$. anisopliae concentration (i.e. LC $_{50}$-value) (Figure 4).

For describing the relationship between concentration of $M$. anisopliae and the respective $\mathrm{LT}_{50}$, an overall model was applied using the above established function on time-dependency of the intercept and slope for the resulting probit regression lines. The overall model is as follows:

$\log L C_{\mathrm{s} 0}=\frac{- \text { intercept }}{\operatorname{slope}}$

$$
\log L C_{50}=\frac{-\left(a+b x+\frac{c}{\sqrt{x}}\right)}{d \cdot \exp (e \cdot x)}
$$

Where the intercept and the slope is depending on the time (in days) after inoculation of the fungus; i.e. Slope $=a \times \exp (b \times x)$ and Intercept $=a+b x+c / \sqrt{x}$ where, " $x$ " is the time in days after inoculation. Parameter of the function is presented in Table 3 and Figure 1.

Other log LCxx-values can be calculated by applying the following function:

$\log L C_{50}=\frac{Y_{\text {sx }}-\text { inyercept }}{\text { slope }}$

Where $Y_{x x}$ is the probit value transformed from the required percentage mortality " $x x$ ". The obtained lines for $\mathrm{TL}_{50}, \mathrm{TL}_{30}$, and $\mathrm{TL}_{70}$ are presented in Figure 5. It shows that the predicted line for $\mathrm{LT}_{50}$ fits well to the obtained $\mathrm{LC}_{50}$-values obtained in the study. 


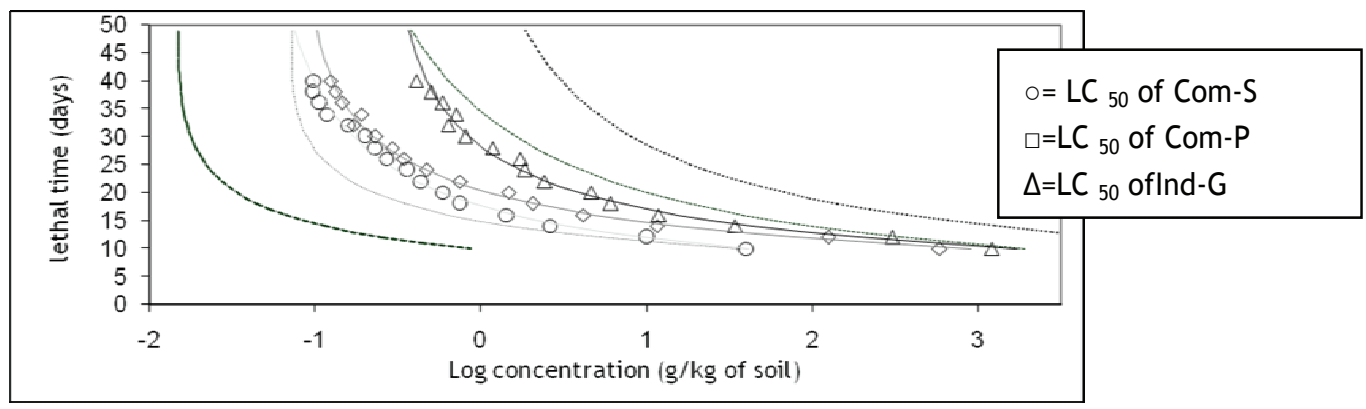

Figure 4. $\mathrm{LC}_{30}, \mathrm{LC}_{50}$, $\mathrm{LC}_{70}$ of three preparation of $\mathrm{M}$. anisopliae

Relative potencies of Com-S ranged between 4.013 to 30.194 and Com-P was 2.071 to 5.047 using Ind-G reference (activity=1), did not change for different evaluation dates. This was verified by linear regression (Figure 5), where the regression coefficient resulted not significantly different from zero $(F=13.85, \mathrm{df}=11$,$) . Due$ to the low activities of pathogens at the beginning of the evaluation period obtained potencies were more variable than at the end of the experiment and accordingly confidence interval for the relative potencies resulted much wider than at the end of the experiment. At the beginning, the relative potencies of Com-S was very high (30.2) as compared to Com-P(2.1), at the final period, the relative potencies became (4.2) and (3.3), respectively. Variations in potencies were observed for Com-S at the beginning than Com-P, finally it became more or less constant for both formulations. So the biological activities of Com-S were more effective than both barley grain and powder formulation, and also the Com$P$ was more effective than Ind-G.



Figure 5. Relative potencies obtained for comparing Com-P and Com-S against Ind-G as its value equals one.

\section{DISCUSSIONS}

In this experiment two preparations of commercial strain and one preparation of indigenous strains of $M$. anisopliae were assessed individually to determine the biological activity of these pathogens against $C$. acuta. These three formulations were found to be effective to kill the test insects. The $\operatorname{LC}_{50}$ value of Ind-G(0.41 $\mathrm{g} / \mathrm{kg}$ of soil) was higher as compared to Com-P $(0.11 \mathrm{~g} / \mathrm{kg}$ of soil) and Com-S $(0.10$ 
$\mathrm{g} / \mathrm{kg}$ of soil). In this experiment, the $\mathrm{LC}_{50}$ value of Com-S and Com-P were $10^{4}$ and $1.2 \times 10^{4}$ spores/g soil, respectively, at about $25 \pm 2^{\circ} \mathrm{C}$. Correspondingly, Ansari (2004) found $\mathrm{LC}_{50}$-values ranging between $2.5 \times 10^{4}$ and $10^{5}$ conidia/g soil using $M$. anisopliae (CLO53) for controlling Hopliaphilanthus at $25^{\circ} \mathrm{C}$. However, it is observed that the fungus activity is affected by temperature. Therefore, the $\mathrm{LC}_{50}$ values might be variable with temperature. According to the formula provided by Keller et al. (2002) the $\mathrm{LC}_{50}$ value of Ind-G was equivalent to $3.79 \times 10^{9}$ spores $/ \mathrm{g}$ soil. Similar finding was observed by Brucket al. (2005), the $\mathrm{LC}_{5}$ o value ranged from $2.7 \times 10^{6}$ to $1.8 \times 10^{8}$ spores/g dry soil when tested 3 isolates (F52, ATCC62176 and ARSEF5520) of M. anisopliae against Delia radicum (L) larvae. The high $L_{50}$ value of the Ind-G might be due to the use of nine month stored product. The shelf life of the product should be studied/assessed to see the effect of storage time on the virulence of $M$. anisopliae. This finding suggests that indigenous strains can be mass produced to reduce the import of exotic strains. In the present study, The $\mathrm{LC}_{50}$ values for both strains showed that $M$. anisopliae had potential as biological agents for controlling white grubs. As it was found effective in the laboratory condition further field studies are necessary to evaluate the field efficacy of fungus against white grubs. A future study on the effect of storage time on the virulence of $M$. anisopliae, with its different formulations is also recommended.

\section{CONCLUSION}

From these results it is concluded that the entomopathogenic fungi could be a safe microbial control agents in managing white grub. Research should be continued to obtain more virulent strains of the fungus. As indigenous and commercial strains of $M$. anisopliae were effective against of $C$. acuta, it is imperative to test against other important insect pests of Nepal. As laboratory work was encouraging it should be tested under farmers' field condition. The shelf life of the product should be addressed to see the effect of storage time on the virulence of $M$. anisopliae, some research are needed.

\section{ACKNOWLEDMENT}

This study is part of a collaborative project between the Nepal Agricultural Research Council (NARC), the International Potato Center (CIP), Peru, and the Institute of Agriculture and Animal Science (IAAS) funded by the Austrian Development Agency (ADA), Austria, and the German Federal Ministry for Economic Cooperation and Development (Bundes ministerium für wirtschaftliche Zusammenarbeit und Entwicklung, BMZ), Germany. The authors are thankful to all those who provided technical and financial support to conduct this research.

\section{REFERENCES}

Abbott, W.S. 1925. A method for computing the effectiveness of an insecticide. Journal of Economic Entomology 18:265-267. 
Ansari, M. A., S. Vestergaard, L. Tirry and M. Moens. 2004. Selection of a highly virulent fungal isolate, Metarhiziumanisopliae CLO 53, for controlling Hopliaphilanthus. Journal of Invertebrate Pathology 85:89-96.

Bruck, D. J, J. E. Snelling, A. J. Dreves, S. T. Jaronski. 2005. Laboratory bioassay of entomopathogenicc fungi for control of Delia radicum (L) larvae. Journal of Invertebrate Pathology 89:179-183.

Butt, T. M., C. W. Jackson and N. Magan. 2001. Introduction fungal biological control agents: Progress, problems and potential. In: T.M. Butt, C.W. Jackson and N. Magan (eds.) Fungal Biological Control Agents: Progress, Problems and Potential. CABI Publishing, Wallingford, UK. pp. 1-8.

Ferron, P. 1985. Fungal control. In: G. A. Kerkut and L. I. Gilbert (eds.) Comprehensive Insect Physiology, Biochemistry and Pharmacology.Pergamon, Oxford. pp. 313-346.

Finney, J. R. 1971. Probit analysis. (3rd ed.) Cambridge University Press. Cambridge, UK $333 p$.

Fuxa, J. R. 1987. Ecological considerations for the use of entomopahtogens in IPM.Annual Review of Entomology 32:225- 251.

Guppy, J. C. and G. D. Harcourt. 1970. Spatial pattern of the immature stages and teneral adults of Phyllophaga spp. (Coleoptera: Scarabaeidae) in permanenet meadow. Canadian Entomologist 102:1345-1359.

Joshi, S. L., B. B. Karmacharya and B. R. Khadge. 1991. Plant protection trainer's manual No. 14. Manpower Development Agriculture Project. Kathmandu, Nepal. 396p.

Keller, S., P. Kessler, D. B. Jensen and C. Schweizer. 2002. How many spores of conidia are needed to control Melolonthamelolonthapopulations. In: S. Keller (eds.), Integrated control of soil pests "Melolontha". Proceeding of the meeting, 24-26 September 2001,IOBL, Switzerland, IOBC/WPRS Bulletin 25:59-64.

Maharjan, R., S. Aryal, B. P. Mainali, S. Bista, D. N. Manandhar, Y. P. Giri and R. B. Paneru. 2004. Survey on magnitude of insecticides use in vegetable crops. In: B. B. Khatri. B. P. Sharma, P. P. Khatiwada, K. P. Paudyal, B. R. Khadge and H. N. Regmi (eds.) Proceeding of the $4^{\text {th }}$ national workshop on horticulture. Advances of Horticultural Research in Nepal, 2-4 March, 2004, Kathmandu. Horticulture Research Division and National Agriculture Research Institute, Nepal Agricultural Research Council, Khumaltar. Lalitpur. pp. 390-394.

Mazodze, R.and P. Zvoutete. (1999). Efficacy of Metarhiziumanisopliae in the control of blackmaize beetle in the Southeast lowveld of Zimbabwe.Journal of Crop Protection. 18(5):571-515.

NMRP. 1997. Annual report. Lumle Agriculture Research Centre, Pokhara, Kaski, Nepal. 26p.

Oya, S. 1995. Control of Scarabaeid larvae in sweet potato by the entomopathogenic nematode Steinernemakushidai.In: Geraldine Grey (ed.) Biological Control in Systems of Integrated Pest Management. FFTC, Book series no. 47p.

Oya, S. 1996. Control of Scarabaeid larvae on sweet potato by Entomopathogenic nematode,SteinernemakushidaiMumiya.In; Proceeding of the International Symposium on the Use of Biological Control Agents under Integrated Pest Management, December 1996.FFTC Book Series No. 47.Food and Fertilizer Technology Center Republic of China.Taiwan.pp. 70-77.

Palikhe, B. R., P. R. Addhikari and L .P. Kharel. 2003. Present status of plant protection services in Nepal. In: Proceedings of a Nation Seminar, Kathmandu, 25-26 September, 2002.. F.P. Neupane (ed.) Integrated Pest Management in Nepal, Himalayan Resources Institute, Kathmandu, Nepal. pp.11-21. 
Pokhrel, M. R. 2004. Field survey of white grubs and laboratory evaluation of Metarhiziumanisopliae (Metsch.)Sorokin for its control with side effects onBombyxmori L in. M. Sc. Ag. Thesis (Unpublished), Tribhuvan University, Institute of Agriculture and Aninal Science, Rampur, Chitwan, Nepal.134p.

Potter, D. A., C. G. Patterson and C. T. Redmond. 1992. Influence of turf grass species and tall fescue endophyte on feeding ecology of Japanese beetle and Southern masked chafer grubs. Journal of Economic Entomology 85:900-909.

Prasad, S. K. and C. Thakur. 1959. White grub Lachnosternaconsanguinea Blanch: A new menace to sugarcane. Indian Journal of Entomology 21:184-189.

Raodeo, A. K. 1974. White grubs menace in MaharastraState. White Grubs Newsletter 1: 1113.

Schweigkofler, W. and R. Zelger. 2002. Were control measures responsible for the decline of Melolonthapopulations in South Tyrol. In: S. Keller (ed.) Integrated Control of Soil Pest "Melolontha" Proceedings of the Meeting, 24-26 September 2001.IOBL, Switzerland,. IOBC/WPRS Bulletin 25:65-72.

Upadhyaya, N. S. 2003. Status of community integrated pest management in Nepal. In: F. P. Neupane (ed.) Proceeding of a national seminar on integrated pest management in Nepal. 25-26 September, 2002, Kathmandu. Himalayan Resource Institute, Kathmandu, Nepal. pp.209- 216. 